\title{
Persistent Organochlorine Pesticide Residues in Fish from Guanting Reservoir, People's Republic of China
}

\author{
Y. Z. Sun, X. T. Wang, X. B. Xu
}

Research Center for Eco-Environmental Sciences, Chinese Academy of Sciences, Beijing, 100085, People's Republic of China

Received: 5 September 2004/Accepted: 19 November 2004

Organochlorine compounds such as $\mathrm{HCH}$, DDT and hexachlorobenzene (HCB) are ubiquitous anthropogenic chemicals in the environment. The products of $\mathrm{HCH}$, DDT and HCB have been widely used from 1950 to 1983 in China. The yields of organochlorine pesticides (OCPs) including $\mathrm{HCH}$ and DDT in this country were 4.9 million tons and 0.43 million tons, accounting for $33 \%$ and $20 \%$ of the world total production, respectively (Hua and Shan, 1996). These compounds were once used on a large scale in agricultural practices. Being lipophilic, persistent and toxic in nature, organochlorines are readily accumulated in the tissues of non-target living organisms (Phillips, 1980; Connell, 1995) where they may cause detrimental effects, and they have been detected in a wide range of environmental media, including biota (Fowler, 1990; Tanabe et al., 1994).

Guangting Reservoir is located in the northwest of Beijing (shown in Figure 1) with a capacity of 2.27 billion cubic meters. It was once one of main water sources as agricultural, industrial and drinking water for the people living in Hebei province and Beijing prefecture. But it was contaminated seriously by agricultural, industrial, manufacturing discharge and municipal sewage disposal practices from the upriver estuaries in the 1980s, so it could not be used as drinking water source since then. With rapid industrialization and urbanization, Beijing is now facing a serious problem on shortage of water, and Guanting Reservior is expected to resume the status of drinking water resource before 2008 after environmental management and remediation.

As the most rapid uptake of xenobiotic organic contaminants (up to 400-450 Dalton ) by fish is via the gills rather than food (Ranadall et al., 1998), water mass characterization is likely to be much more important than diet in explaining concentration of contaminants such as polychlorinated biphenyls (PCBs) and OCPs in fish. Moreover, fish is on the top of food web in the water ecosystem and thus higher concentration of persistent organic pollutants (POPs) is accumulated by biomagnification in its body. Hence fish could be used as bioindicator for water quality (Mormede et al., 2003). Freshwater fish species represent important sources of food protein in many regions of China. Six fish species investigated in this study are consumed by the population inhabited in the area. This is due to the higher accessibility of theses species for the fishermen and their low costs on the 


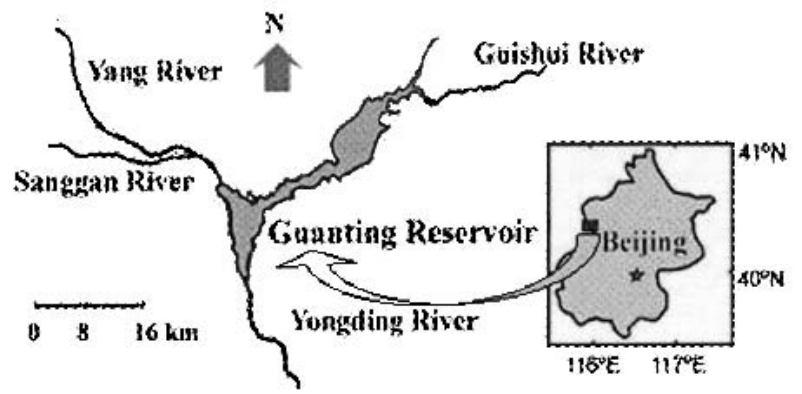

Figure 1. Map of Guanting Reservoir and its location in Beijing

local markets. So their contamination is also a matter of concern for human health.

The contamination of organochlorines (including OCPs and PCBs), polycyclic aromatic hydrocarbons (PAHs), phthalate esters (PAEs) and n-alkanes in water, suspended particle matters and sediment in Guanting Reservoir and the Yongding River have been investigated comprehensively (Wang, 2003; Wang et al. 2004), but no information is available on the level of OCPs in organisms especially fish from the reservoir. The objectives of this study were to determine the levels of pollution with persistent organochlorine pesticides in several fish species collected from Guanting Reservoir and to compare them with reported data from other inland water bodies and to health-based standards for fish consumption.

\section{MATERIALS AND METHEODS}

A composite stock standard solution of OCPs comprising $\alpha-, \beta-, \gamma-, \delta-\mathrm{HCH}$ and $o, p^{\prime}$ - and $p, p^{\prime}$-DDE, DDD, DDT was purchased from National Research Center for Certified Reference Materials of China at concentration of $100 \mathrm{mg} / \mathrm{L}$. HCB standard solution with a concentration of $100 \mathrm{mg} / \mathrm{L}$ was also bought from the center mentioned above. Decachlorobiphenyl (PCB209) was from Supelco (Bellfonte, USA). The desired concentration solution of OCPs was obtained by diluting the standard solution with iso-octane. Anhydrous sodium sulfate was heated in a furnace at $600^{\circ} \mathrm{C}$ for $5 \mathrm{hr}$ to remove impurities.

Silica gel (100-200 mesh) was activated in drying oven at $130^{\circ} \mathrm{C}$ for $16 \mathrm{hr}$ and then deactivated with $3 \%$ water $(w / w)$ after it was cooled down to room temperature in a desiccator. All solvents used were of analytical grade and redistilled in all-glass system to remove impurities prior to use.

Fish samples investigated including Feral carp (Cyprinus carpio), Wheat head gudgeon (Pseudorasbora pavra), Color gudgeon (Abbottina rivularis), Chinese bitterling (Rhodeus sinensis), Silver xenocypris (Xenocypris argenteai) and Hemiculter leucisculus (Hemiculter leucisculus) (abbreviated to FC, WHG, CG, CB, $\mathrm{SX}$, and HL, separately) were collected from local fishermen living in the Guanting prefecture in October 2002. The fish samples were wrapped in precleaned 
Table 1. Common, length, weight, lipid content and food of fish samples surveyed from Guanting Reservoir.

\begin{tabular}{lllll}
\hline \multicolumn{1}{c}{ Common } & $\begin{array}{c}\text { Length } \\
(\mathrm{cm})\end{array}$ & $\begin{array}{c}\text { Weight } \\
(\mathrm{g})\end{array}$ & $\begin{array}{l}\text { Lipid } \\
(\%)\end{array}$ & \multicolumn{1}{c}{ Food } \\
\hline Feral carp & $8.3-11.3$ & $9.9-11.4$ & 3.5 & Algae, shrimp, advanced plant \\
Wheat head gudgeon & $6.9-9.3$ & $3.6-4.4$ & 1.9 & Plant, isopod, algae \\
Color gudgeon & $8.7-10.3$ & $8.9-10.1$ & 9.5 & Algae, advanced plant \\
Chinese bitterling & $6.8-7.2$ & $4.7-5.5$ & 7.7 & Zooplankton, insect larvae \\
Silver xenocypris & $6.8-7.4$ & $4.8-5.2$ & 2.7 & Algae, zooplankton, shrimp \\
Hemiculeer leucisculus & $10.3-11.7$ & $9.8-10.8$ & 15.1 & Amphipod, phytoplankton \\
\hline
\end{tabular}

aluminum foils and kept at $-24^{\circ} \mathrm{C}$ refrigerator until analyses. In order to minimize effects of size (and therefore age) on fish contamination, individuals of the same species were selected as homogeneously in length as possible. Due to the small size, the total fish body was considered for analysis. The length and weight of each fish were measured before the analytical procedure. The large-size fishes such as catfish, chub and herring, would be used to determine the distribution of OCPs in different organs and tissues, and the results would be summarized in another paper. Collected fish information on the length, weight, lipid content and feeding preferences is given in Table 1.

After thawing, the whole fish $(n=10)$ for each species was well homogenized in a tissue homogenizer. Approximately $10 \mathrm{~g}$ (wet weight) of homogenized sample (depending on the lipid content for each species) was transferred to a mortar, $30 \mathrm{~g}$ of anhydrous sodium sulfate was added, and then ground until the mixture was free-flowing. Finally the resulting powder was transferred to a clean beaker, covered with aluminum foil and equilibrated for $16 \mathrm{hr}$ in a desiccator for extraction. The samples were extracted with $200 \mathrm{ml}$ of hexane/acetone $(1: 1, \mathrm{v} / \mathrm{v})$ in hot Soxhlet extraction mode for $24 \mathrm{hr} .1 \mathrm{ml}$ of PCB209 solution at a concentration of $60 \mu \mathrm{g} / \mathrm{L}$ was added before extraction as a surrogate analyte. The lipid content of each sample was determined gravimetrically by evaporating an aliquot of the extract to constant weight in an oven at $105^{\circ} \mathrm{C}$ for $12 \mathrm{hr}$. The remaining extract was dried with anhydrous sodium sulfate and then concentrated in a rotary vacuum evaporator to about $5 \mathrm{~mL}$. Further lipid removal and clean-up were achieved by using concentrated sulfuric acid wash and silica gel (partially deactivated) chromatography sequentially. The eluates were concentrated by a gentle nitrogen steam to $200 \mu \mathrm{L}$, and then transferred to vials for $\mathrm{GC}$ injection.

The instrumental analyses were performed by GC6890- $\mu$ ECD (Agilent 6890 series II equipped with a ${ }^{63} \mathrm{Ni}$ electron capture detector). A DB-5 fused silica capillary column ( $30 \mathrm{~m} \times 0.25 \mathrm{~mm}$ id, and $0.25 \mu \mathrm{m}$ film thickness) was used. The injection mode was splitless and the purge time was $0.75 \mathrm{~min}$. Nitrogen was used as carrier gas and make-up gas. Detector and injector temperature were $300^{\circ} \mathrm{C}$ and $280^{\circ} \mathrm{C}$, respectively. The GC oven temperature program was carried out as follows: initial temperature $50^{\circ} \mathrm{C}$ held for $1 \mathrm{~min}$, increased to $280^{\circ} \mathrm{C}$ at $4{ }^{\circ} \mathrm{C} / \mathrm{min}$, then held for 10 min. Peak identification of HCB, HCHs (including $\alpha-, \beta-, \gamma-$ and $\delta-\mathrm{HCH}$ ) and DDTs (including $p, p^{\prime}$-DDE, DDD, DDT and $o, p^{\prime}-\mathrm{DDT}$ ) was made by comparison of 


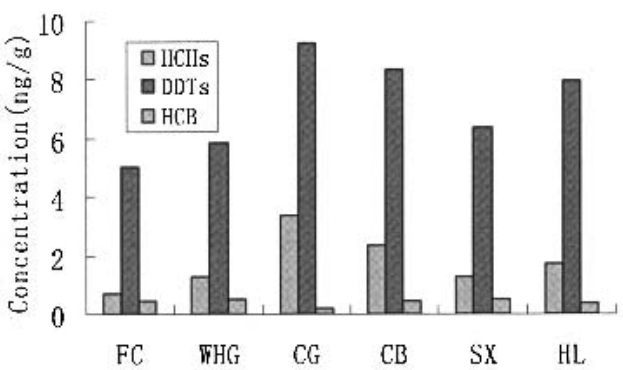

Figure 2. Distribution of HCHs, DDTs and HCB in different fish species

retention time with corresponding standards and confirmed on an Agilient 6890 GC equipped with a model 5973 mass selective detector (MSD). The quantification of the analytes was performed by comparison to external standard. Limits of detection (LOD) were defined as the lowest quantity of injected standard giving a $3: 1$ signal versus noise value in blank sample. The LODs of $\alpha-, \beta-, \gamma-, \delta-\mathrm{HCH}$ and HCB were $43.2,90.0,95.9,58.4$ and $41.6 \mathrm{pg} / \mathrm{g}$ lipid weight, and those of $p, p^{\prime}-\mathrm{DDE}$, $p, p^{\prime}$-DDD, $o, p^{\prime}$-DDT, $p, p^{\prime}$ - DDT were $62.7,65.9,61.2,80.5$, and $41.6 \mathrm{pg} / \mathrm{g}$ lipid weight, respectively. Matrix spike analyses were made by spiking standard solution into pure corn oil. The recoveries of $\alpha-, \beta-, \gamma-, \delta$ - $\mathrm{HCH}$ and $\mathrm{HCB}$ were $57.4 \pm 7.3$, $64.2 \pm 6.7,57.8 \pm 4.4,65.9 \pm 9.8 \%, 63.8 \pm 7.3 \%$, and those of $p, p^{\prime}$-DDE, $p, p^{\prime}$-DDD, $o, p^{\prime}$-DDT, $p, p^{\prime}$-DDT were $68.1 \pm 14.2,69.5 \pm 19.1,73.6 \pm 3.4$ and 79.2 $\pm 17.4 \%(\mathrm{n}=7)$, respectively. Quality assurance criteria for these organochlorine analyses were based on the measure of blank pure corn oil including the whole analytical procedure. All residue concentrations below method detection limits were regarded to be equal to zero in calculation of sum, means and so on. The recoveries of surrogate (PCB209) in all samples tested were between 90-110\%. All results including lipid content and concentration of target analysts reported in the study were means of duplicate analyses. Concentrations were expressed in ng/g on a wet weight basis and all results were not corrected for recoveries.

\section{RESULTS AND DISCUSSION}

Distributions of HCHs, DDTs and HCB in different fish species studied are shown in Figure 2. The OCP concentration (sum of $\mathrm{HCHs}+\mathrm{DDTs}+\mathrm{HCB}$ ) in fish was in the range of $6.18 \mathrm{ng} / \mathrm{g}$ in Feral carp to $12.78 \mathrm{ng} / \mathrm{g}$ in Color gudgeon with a value of $9.33 \mathrm{ng} / \mathrm{g}$. Levels of OCPs in different fish species were not similar though they are similar in size, and in the following order: Color gudgeon $>$ Chinese bitterling $>$ Hemiculter leucisculus $>$ Silver xenocypri $>$ Wheat head gudgeon $>$ Feral carp. The dominant part of OCP residue in fish was DDTs that accounted for $72.20-81.49 \%$, with an average of $77.04 \%$, followed by $\mathrm{HCHs}$ from 11.70 to $26.32 \%$. While $\mathrm{HCB}$ contribution to total OCPs was the lowest, percentages of HCB in OCP residues were only about $1.49 \%$ to $6.83 \%$. In six fish species studied HCHs concentrations were in the range from 0.72 to $3.36 \mathrm{ng} / \mathrm{g}$, and with an average of $1.78 \mathrm{ng} / \mathrm{g}$. HCHs was the highest in Color gudgeon with a value of $7.15 \mathrm{ng} / \mathrm{g}$, followed by Chinese bitterling a value of $2.38 \mathrm{ng} / \mathrm{g}$. The concentration of HCHs was the lowest in Feral 

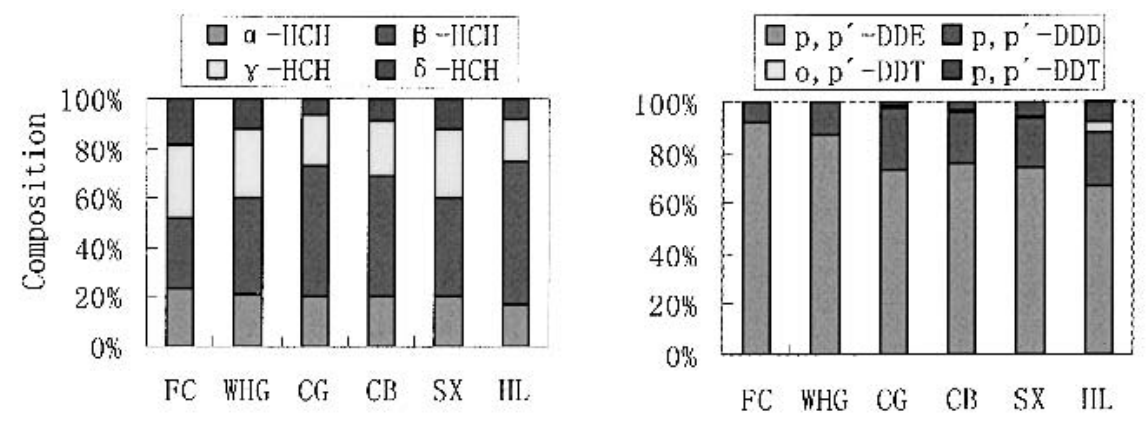

Figure 3. Percentage distribution of $\mathrm{HCH}$ isomers and DDT analogues in different fish species.

carp with an value of $0.72 \mathrm{ng} / \mathrm{g}$. DDTs concentrations were in the range from 5.04 to $9.23 \mathrm{ng} / \mathrm{g}$, and with an average of $7.13 \mathrm{ng} / \mathrm{g}$ wet weight. DDTs was the highest in Chinese bitterling with a value of $9.23 \mathrm{ng} / \mathrm{g}$, followed by Chinese bitterling and Hemiculter leucisculus with values of 8.33 and $7.95 \mathrm{ng} / \mathrm{g}$, respectively. The concentration of DDTs was the lowest in Feral carp with a value of $5.04 \mathrm{ng} / \mathrm{g}$.

HCB residue was detected in each fish species, but its contamination levels were lower compared with $\mathrm{HCH}$ and DDTs. The concentrations of $\mathrm{HCB}$ in fish were about $0.19 \mathrm{ng} / \mathrm{g}$ to $0.54 \mathrm{ng} / \mathrm{g}$, with an average of $0.42 \mathrm{ng} / \mathrm{g}$. HCB occurs in the environment as a result of wide range used as a fungicide, manufacturing, combustion (Vallack et al., 1998; Bailey, 2001) and by-product of the manufacture of chlorinated hydrocarbons (Villanueva et al., 1974). Its low body burden may be explained from its persistence and physical properties which favors relatively high mobility via atmosphere and deposition from its high emissions. Moreover, HCB has similar levels in the six species except the Color gudgeon that lives in the sediment, which indicate that it was mainly bioconcentrated from water across gill, and it is in accordance with the laboratory experiment by Randall et al. (1998).

Perentage compositions of $\mathrm{HCH}$ isomers and $p, p^{\prime}$-DDT and its isomer and metabolites in different fish species are illustrated in Figure 3. $\alpha-, \beta-, \gamma$ - and $\delta$-HCH isomers were also detected in all species, The main residue component of $\mathrm{HCH}$ isomers in fish was $\beta-\mathrm{HCH}$, which had the highest concentration in all species and was in the range of 0.21 to $1.77 \mathrm{ng} / \mathrm{g}$, with an average of $0.85 \mathrm{ng} / \mathrm{g}$, followed by $\gamma-\mathrm{HCH}$ and $\alpha-\mathrm{IICH}$ from 0.21 to $0.70 \mathrm{ng} / \mathrm{g}$ and 0.17 to $0.68 \mathrm{ng} / \mathrm{g}$, with means of 0.40 and $0.36 \mathrm{ng} / \mathrm{g}$, respectively. $\beta-\mathrm{HCH}$ is metabolically inactive and the most persistent one of $\mathrm{HCH}$ isomers, which can explain the reason for the highest percentage in the composition of $\mathrm{HCH}$ isomers in all the samples. The ratio of $\alpha-\mathrm{HCH}$ to $\gamma-\mathrm{HCH}(\alpha / \gamma)$ can be used to determine whether recent exposure to technical $\mathrm{HCH}$ and/or lindane occurred. The value of $\alpha / \gamma$ would be in the range of 5.0 to 5.4 for technical $\mathrm{HCH}$ and nearly zero for lindane manufactured in China (Wang ct al., 2003). Low ratios, particularly below one, indicate recent lindane input. The ratios found in different fish species in present study were in the range of 0.75 to 1.03 , indicating that recent input of lindane into the environment had 
Table 2. Representative examples of OCPs in fish samples (ng/g wet weight) from different fresh water bodies.

\begin{tabular}{llllll}
\hline Locality & Fish & HCB & HCHs & DDTs & References \\
\hline Mumbai, India & Dogfish & NA & $33.73^{\mathrm{a}}$ & $32.56^{\mathrm{a}}$ & Pandit et al. (2002) \\
Arctic lake & Lake trout & $1.0^{\mathrm{a}}$ & $1.0^{\mathrm{a}}$ & $2.8^{\mathrm{a}}$ & Wilson et al. (1995) \\
South Sinai & Bouri fish & $20.3^{\mathrm{a}}$ & NA & $18.2^{\mathrm{a}}$ & Nemr et al. (2004) \\
Texas & Various fishes & NA & NA & $76-2117$ & Wainwright et al. (2001) \\
San Francisco & Various fishes & NA & NA & $5.3-85$ & Davis et al. (2002) \\
Baiyangdian lake & Carp & NA & $110.7^{\mathrm{a}}$ & $124.4^{\mathrm{a}}$ & Dou et al. (1996) \\
Taihu lake & Various fishes & NA & $3.4^{\mathrm{a}}$ & $189.0^{\mathrm{a}}$ & Dong et al. (2002) \\
Guanting reservoir & Various fishes & $0.42^{\mathrm{a}}$ & $1.78^{\mathrm{a}}$ & $7.13^{\mathrm{a}}$ & This study \\
\hline
\end{tabular}

a: average concentration

NA: not available

probably occurred.

As we know, DDT has been extensively used in China and abroad in the past decades and is still significantly applied for vector control against malaria in the low latitudes. $p, p^{\prime}$-DDE is the most persistent metabolites of $p, p^{\prime}$-DDT. In the composition of DDTs, $p, p^{\prime}$-DDE is dominant in all kinds of fishes. $p, p^{\prime}$-DDE, $p, p^{\prime}$-DDD and $p, p^{\prime}$-DDT were also detected in all species, while o, $p^{\prime}$-DDT was detected only four in six species. The concentrations of $o, p^{\prime}$-DDT in Wheat head gudgeon and Feral carp were lower than their LODs. The residue concentration of $p, p^{\prime}$-DDE in all species was in the range of 4.61 to $6.74 \mathrm{ng} / \mathrm{g}$, with an average of $5.45 \mathrm{ng} / \mathrm{g}$, followed by $p, p^{\prime}$-DDD, from 0.41 to $2.29 \mathrm{ng} / \mathrm{g}$, and with a mean of $1.33 \mathrm{ng} / \mathrm{g}$. Concentrations of $p, p^{\prime}$-DDT and $o, p^{\prime}$-DDT in all species were significantly lower than those of $p, p^{\prime}$-DDE, $p, p^{\prime}$-DDD. The ratio of $\left(p, p^{\prime}\right.$-DDE + $p, p^{\prime}$-DDD) $/ p, p^{\prime}$-DDT was also used to determine whether recent exposure to DDT occurred, with the ratio increasing over time as the DDT degraded. The ratio found in fish in this study ranged from 10.93 to 278.83 with a mean of 112.89 . The ratios were greatly above 1 for different species, indicating an old use of technical DDT.

The lipid contents in each species (Table 1) were significantly different and in the descending order: Hemiculter leucisculus $>$ Color gudgeon $>$ Chinese bitterling $>$ Feral carp $>$ Silver xenocypris $>$ Wheat head gudgeon. It is obvious that fish with high lipid content accumulated more of HCHs and DDTs than lean fish which is in accordance with results reported previously (Fairey et al., 1997; Roche, 2000). But linear relation between HCHs or DDTs and lipid content was not found. Significant, but weak correlations were found between lipid content and contaminant concentration for HCHs $\left(\mathrm{R}^{2}=0.27\right)$ and DDTs $\left(\mathrm{R}^{2}=0.54\right)$ in different fish species. A high positive correlation $\left(\mathrm{R}^{2}=0.86\right)$ was found between $H C H s$ and DDTs residue in fish species due to a probable similar bioaccumulation.

To understand the status of OCPs contamination in fishes studied, the levels of HCHs, DDTs and HCB determined in the present study were compared with other results from other water bodies in China and other countries (shown in Table 2). It is clear that there is no evidence to suggest that Guanting Reservoir is seriously contaminated currently with HCHs, DDTs and HCB compared to the reported data. 
Organochlorine compounds pose a potential threat especially to human health and aquatic biota. DDT and HCB were included in the dozen "dirty" POPs targeted by the Stockholm Convention. The maximum permissible levels of toxic organic pollutants for protection of human health and aquatic biota have been established in many countries. The residue levels of HCHs and DDTs in fish were far below the national food standard of China $(1000 \mu \mathrm{g} / \mathrm{kg}$ for HCHs and $2000 \mu \mathrm{g} / \mathrm{kg}$ for DDTs) (MOH, 1994)). The Canadian tissue residue guidelines (CCME, 1999) and US Great lakes water quality initiative criteria (EPA, 1995) for protection of fish-eating wildlife are much lower than human health guidelines with values of 14 and $39 \mathrm{ng} / \mathrm{g}$ wet weight respectively. Even compared to these stricter quality guidelines mentioned above, the results in fish species were not exceeded in this study, suggesting that HCHs and DDTs concentration present negligible risk to both humans and wildlife consuming these fish.

It can be inferred from the present study that the levels of OCP (including HCHs, DDTs and HCB) residues found in various fish species investigated are significantly different and quite low and pose no threat to human health and wildlife fed upon them on the basis of existing related quality guidelines. However, further investigation should be carried on as to ascertain if recent input for lindane into the studied environment occurred and where it came from if it really existed.

Acknowledgments. This study was financially supported by the Main Basic Research Development Program (G1999045710) and KIP of CAS (RCEES 9902, 9006). We would like to thank the Chemical Analysis Group of Agilent Technologies Co. Ltd. (China) for GC/MS analysis support.

\section{REFERENCES}

Bailey RE (2001) Global hexachlorobenzene emissions. Chemosphere 43: 167-182.

CCME (1999) Canadian environmental quality guidelines. Canadian Council of Ministers of the Environment. Winnipeg, Manitoba.

Connell DW (1995) Prediction of bioconcentration and related lethal and sublethal effects with aquatic organisms. Mar Pollut Bull 31:201-205.

Davis JA, May MD, Greenfield BK, Fairey R, Roberts C, Ichikawa G., Stoelting MS, Becker JS, Tjeerdema RS (2002) Contaminant concentrations in sports fish from San Francisco Bay, 1997. Mar Pollut Bull 44:1117-1129.

Dong YH et al. (2002) Bioindication of organochlorine pesticides by night heron in Taihu wetland ecosystem. J Appl Ecolo (in Chinese) 13:209-212.

Dou W, Zhao ZX (1996) A study on bioaccumulation of BHC and DDT in fish muscles of different food structure from Baiyangdian lake. Adv Environ Sci (in Chinese) 4:50-56.

EPA (1995) Great Lakes water quality initiative criteria documents for the protection of wildlife, EPA-820-B-95008, U.S. Environmental Protection Agency. Washington, DC: Office of Science and Technology.

Fairey R, Taberski K, Lamerdin S, Johnson E, Clark RP, Downing JW, Newman J, Petreas M (1997) Organochlorines and other environmental contaminants in 
muscle tissues of sportfish collected from San Francisco Bay. Mar Pollut Bull 34:1058-1071.

Fowler SW (1990) Critical review of selected heavy metal and chlorinated hydrocarbon concentrations in the marine environment. Mar Environ Res 35:209-222.

Hua X, Shan Z (1996) The production and application of pesticides and factor analysis of their pollution in environment in China. Adv Environ Sci (in Chinese) 4:33-45.

MOH (1994) Hygienic standard of fresh water fish. GB2736-94. Ministry of Health of P. R. China, Beijing.

Mormede S, Davies IM (1995) Horizontal and vertical distribution of organic contaminants in deep-sea fish species. Chemosphere 50: 563-574.

Nemr AE, Abdallah AMA (2004) Organochlorine contamination in some marketable fish in Egypt. Chemosphere 54:1401-1406.

Pandit GG, Sahu SK, Sadasivan S (2002) Distribution of HCH and DDT in the coastal marine environment. J Environ Monit 4:431-434.

Phillips DJH (1980) Quantitative aquatic biological indicators - Their use to monitor trace metal and organochlorine pollution. Applied Science Publishers, London.

Randall DJ, Connell DWK, Yang R, Wu SS (1998) Concentrations of persistent lipophilic compounds in fish are determined by exchange across the gills, not through the food chain. Chemosphere 37:1263-1270.

Roche H (2000) Organochlorine residues in Europe eel (Anguilla), crucial carp (Caresses) and catfish (Ictalurus nebulous) from Vaquerous Lagoon (French National Nature Reserve of Camargue )-effects on some physiological parameters. Aquat Tocicol 448:443-459.

Tanabe S, Iwata H, Tatsukawa R (1994) Global contamination by persistent organochlorine and their ecotoxicological impact on marine mammals. Sci Total Environ 154:163-177.

Vallack HW, Bakker DJ, Brandt I (1998) Controlling persistent organic pollutants-what next? Environ Toxicol Pharmacol 6:143-175.

Villanueva EC, Jennings RW, Burse VW, Kimbrough RD (1974) Evidencde of chlorobenzo-p-dioxins and chlorodibenzofurans in hexachlocamphenes (toxaphene) (PCC) in biological samples. Fresenius $Z$ Anal Chem 300:387-402.

Wainwright SE, Mora MA, Sericano JL, Thomas P (2001) Chlorinated hydrocarbons and biomarkers of exposure in wading birds and fish of the lower Rio Grande Valley, Texas. Arch Environ Contam Toxicol 40:101-111.

Wang XT, Chu SG, Ma LL, Sun YZ, Li XH, Xu XB (2004) Contamination of priority polycyclic aromatic hydrocarbons in water from Guanting Reservoir and the Yongding River, China. Bull Environ Contam Toxicol 72:194-201.

Wang XT, Chu SG, Xu XB (2003) Organochlorine pesticide residues in water from Guanting Reservoir and Yongding River, China. Bull Environ Contam Toxicol 70:351-358.

Wilson R, Allen-Gil S, Griffin D, Landers D (1995) Organochlorine contaminants in fish from an Arctic lake in Alaska, USA. Sci Total Environ 160-161:511-519. 